\title{
The Politics of Atonality during the Thaw and Beyond
}

\author{
INESSA BAZAYEV
}

\begin{abstract}
The article provides a critical survey of harsh Soviet attacks on atonal music both foreign and domestic, which began to take root about a decade after the formation of the Soviet Union and continued through the Soviet period. To better contextualize the criticism of atonality within the Soviet Union, the author first discusses the thriving state of atonality prior and during the first two decades of the formation of the Soviet Union, especially highlighted by performances of works by Schoenberg and Berg, as well as their visits to Russia in the 1910s and 1920s. Then, the political climate drastically changed due to the Resolution of 1932, which sought to eradicate all artistic activities and publications that did not comply with Socialist Realism. The term "atonality" became a taboo and was used as a weapon to smear the reputation of Soviet composers. Finally, the article concludes with a brief summary of selected publications by theorist Yuri Kholopov, who tried to re-validate atonality. His creation of the new term—neotonality (1980s) — permitted him to discuss atonal music freely, without the use of the so-called "taboo" term that permeated the Soviet years, allowing open discussion of music by foreign and domestic composers.
\end{abstract}

In official Soviet publications on contemporary music from the 1950s and 1960s, the terms "atonality" [atonal'nost'] and "twelve-tone music" [dvenadtsatitonovaya muzïka] were considered taboo. When used, they functioned to either smear the reputation of Soviet composers or condemn the works of their Western counterparts, especially members of the Second Viennese School. This was an extension of the preceding two decades of systematic repression of atonal experimentation. The story of Soviet music in those murky years, between the start of the Cultural Revolution in the late 1920s and Stalin's death in 1953, is a familiar one, with long chapters on the activities of the Russian Association of Proletarian Musicians (RAPM), the Resolution on Arts (1932) and the imposition of the Socialist Realist aesthetic, denunciation of Shostakovich's Lady Macbeth of Mtsensk District (1936), non-performance of Prokofiev's works commissioned by the state (1936-1941), World War II, the onset of anticosmopolitanism, Zhdanovshchina with its anti-formalist campaigns of 1948 and 1949, and many, many others. This article concentrates on the years that followed-the Thaw and beyond. ${ }^{1}$ First, it examines the official criticism, written by prominent members of the musical community that included composers, conservatory professors, and students who published on the pages of Sovetskaya Muzika (the state organ of Soviet musicology), targeting talented budding composers who were once again exploring atonality. Second, it juxtaposes that official stance and rhetoric with contemporaneous publications on atonality by arguably the most influential Russian theorist, Yuri Kholopov (1932-2003), who set out to

\footnotetext{
${ }^{1}$ The "Thaw" refers to the period after Joseph Stalin's death (1953-1964), in which his successor Nikita Khrushchev began the process of de-Stalinization, which eased censorship and persecution. For more on this period, see Pyotr Vayl' and Aleksandr Genis, 60-iye: mir sovetskogo cheloveka [The '60s: The World of a Soviet Person], Second Corrected Edition (Moscow: Novoye literanurnoye obozreniye, 1998).
} 
re-legitimize atonality. Kholopov's approach to analysis of atonal music (first by Russian and Soviet composers and later by Western ones as well) was an attempt to counter the official negative narrativean attempt that combined Western and Russian theoretical thoughts. My argument here is that in order to legitimize atonality in Soviet music-theoretical discourse, Kholopov constructed an indigenous Russian genealogy for the concept, thus positioning it closer to the classics written in the tonal tradition-a move not unlike Schoenberg's claim that his stylistic innovations were rooted in the Austro-German musical tradition.

The works of Russian Futurist composer Nikolai Roslavets (1881-1944), whose compositional practice in the 1910 and 1920s paralleled that of Arnold Schoenberg, played a major role in Kholopov's project of reasserting atonality as a serious area of musical study. To help contextualize Kholopov's reception of atonality, I draw an arc between the early days of the Soviet Union when atonality flourished and composers enjoyed creative freedom, and the revival of atonal theory, which helped legitimize the practice, initiated in the 1960s in Kholopov's writings. By tracing Kholopov's project while positioning it against the official line on contemporary music, I illuminate the tectonic shift in discourse surrounding atonality that began in the late 1950s-thanks, in no small measure, to the intervention of the discipline of music theory.

\section{Atonality in the 1910s and 1920s}

To understand the acute hostility towards atonality in place by the 1950s, we first need to travel back to the pre- and early Soviet period (1910s-1920s), when the Russian intelligentsia (predominantly in St. Petersburg and Moscow) enjoyed an exciting phase of artistic freedom and curiosity toward atonality. This was marked by performances of atonal music, flourishing of organizations that supported innovation in the arts, as well as visits to Russia by Western composers and performers. For instance, the St. Petersburg Association of Contemporary Music, with Futurist composer Arthur Lourié as director, sponsored a great deal of chamber music composed by both Russian and Western modernists, including Debussy and Scriabin. ${ }^{2}$ During the same period, the adjective "contemporary" began to have a double meaning: on one hand, it meant anything composed recently and, on the other hand, it meant anything innovative. $^{3}$

In December 1912, Schoenberg visited St. Petersburg, where he conducted his own orchestral suite, Pelleas and Melisande. Sergey Prokofiev gave public performances of some of Schoenberg's piano music. ${ }^{4}$ The reception was positive, and the promotion of Schoenberg's music continued through the 1920s. ${ }^{5}$ In 1923, Futurist composer Nikolai Roslavets reviewed the music of Schoenberg's Pierrot Lunaire, in which he not only revealed his complex analytical knowledge of this work, but also his deep

\footnotetext{
${ }^{2}$ Amy Nelson, Music for the Revolution: Musicians and Power in Early Soviet Russia (University Park: The Pennsylvania State University Press, 2004), 48-59. Some highlights of St. Petersburg performances from the 1920s included Ernst Krenek's two operas-Der Sprung über den Schatten and Fohnny spielt auf were performed at the Maly Opera Theatre in 1927 and 1928 , respectively. Further, Alban Berg's Wozzeck was premiered at Moscow's Bolshoi Theatre in 1927. Berg attended the performance and was deeply impressed by its "theatrically strong performance." See Boris Schwarz, "Arnold Schoenberg in Soviet Russia," Perspectives of New Music 4, no. 1 (1965): 86, https://doi.org/10.2307/832529.

${ }^{3}$ See Nelson, Music for the Revolution, 48-59.

${ }^{4}$ The performance of Schoenberg's music in Russia during this period was significant. It paralleled other musical developments in Russian music, which included Scriabin's late works and Roslavets's compositions with synthetic chords. ${ }^{5}$ It seems like Schoenberg's warm impression of his visit to St. Petersburg was mutual, so mutual that with the rise of Nazism in 1933, he actually considered immigrating to the Soviet Union. See Ivan Sollertinskiy, Arnol'd Shenberg [Arnold Schoenberg] (Leningrad: Leningrad Philharmonia, 1934).
} 
understanding of Schoenberg's other compositions that had served as breaking points from tonality, paralleling Alexander Scriabin's Prometheus. ${ }^{6}$ Roslavets must have learned about Schoenberg's music during the composer's visit to Russia a decade earlier. In Schoenberg, he found his true inspiration and path to a new way of composing without tonal centers. In his review, Roslavets listed Schoenberg's Drei Klavierstücke, op. 11, and String Quartet no. 2 among Schoenberg's most important works, characterizing Schoenberg's use of the chromatic scale as his "tonality" that could be versatile, allowing freedom of expression within each of Schoenberg's melodies and harmonies. ${ }^{7}$ Further, Roslavets underscored a significant aspect of Schoenberg's music - its multidimensional projections of a motive, both horizontally and vertically, which Roslavets called "synthetic." This is a crucial moment in the article, for Roslavets tried to equate himself as a composer with Schoenberg. Around 1913, Roslavets had invented his own compositional system that was driven by what he called synthetic chords [sintetakkordi]. He defined a synthetic chord as a group of six to eight notes that determined the entire harmonic plan of a given musical composition. ${ }^{8}$ To further explain his own approach, he published a separate biographical sketch about himself and his music, commenting that his innovation was propelled by his wish to free himself from everything that he had learned at the Moscow Conservatory. ${ }^{9}$

Like Schoenberg, then, Roslavets became a pioneer of atonal music. However, he struggled to find recognition in the newly formed Soviet Union. The Russian Association of Proletarian Musicians (RAPM), formed in 1923 and very influential by the late 1920s, attacked any music featuring atonal elements from a Marxist standpoint: such music was too abstract and complex and therefore too divorced from the needs of the masses. ${ }^{10}$

By the early 1930s, Roslavets became deeply disheartened by these denouncements of atonal music, a feeling he expressed in an open letter entitled "On Pseudo-Proletarian Music." ${ }^{11}$ In it, Roslavets defended artistic innovation as truly revolutionary and protested the simplistic style of the RAPM

\footnotetext{
${ }^{6}$ Nikolay Roslavets, “Lunnïy P'ero Arnol'da Shenberga” [Pierrot Lunaire of Arnold Schoenberg], K novïm beregam, no. 3 (1923): 28-33. Of course, Prometheus was the first work that featured Scriabin's "Mystic chord," which was followed by more than a dozen works that disposed of key signatures (op. 58 onwards), were atonal, with many featuring this chord as part of both melody and harmony. For more on this topic, see Inessa Bazayev, "Scriabin's Atonal Problem," Music Theory Online 24, no. 1 (2018), https://doi.org/10.30535/mto.24.1.1.

${ }^{7}$ Roslavets, "Lunnïy P'ero," 30.

${ }^{8}$ Nikolay Roslavets, "Novaya sistema organizatsii zvuka i novïye metodi prepodavaniya teorii kompozitsii: Tezisï doklada" [The New System of Tone Organization and New Methods of Teaching the Theory of Composition: Lecture Theses], unpublished lecture given at the Stravinsky Musico-Vocal courses in Moscow in 1927, RGALI, fond \# 2569. Roslavets's synthetic chord is synonymous with Anglophone post-tonal theory's concept of a set class. See Inessa Bazayev, "Triple Sharps, $Q_{n t}$ Relations, and Symmetries: Orthography in the Music of Nicolaĭ Roslavets,” Music Theory Spectrum 35, no. 1 (Spring 2013): 111-31, https://doi.org/10.1525/mts.2013.35.1.111.

${ }^{9}$ Nikolay Roslavets, "Nik. A. Roslavets o sebe i svoyom tvorchestve” [Nik. A. Roslavets on Himself and His Works], Sovremennaya Muzika, no. 5 (1924): 132-138.

${ }^{10}$ See Yuriy Keldïsh, “Balet 'Stal'noy skok' i yego avtor - Prokofiev,” Proletarskiy muzïkant, no. 6 (1929): 12-19. In this scathing review of Prokofiev's Le Pas d'Acier, the last ballet commissioned by Diaghilev for Ballets Russes, Keldish called it "bourgeois" and an example of "capitalist" music, among others. The article was part of a larger campaign, instigated by RAPM, to smear Prokofiev's reputation in the Soviet Union. In the late 1970s, Keldish apologized for this article. See Simon Morrison, The People's Artist: Prokofiev's Soviet Years (New York: Oxford University Press, 2009), 411. In his review of Shostakovich's The Nose, Daniil Zhitomirskiy discredited young Shostakovich for taking the "wrong turn" in his promising career. Zhitomirskiy noted that the very subject of the opera, which is based on the eponymous story by Nikolay Gogol, "alienates itself" from serious Soviet theatre. He concluded that the music, which is at times cacophonous, is "totally beyond [him]" and will definitely not be understood by the "metal and textile workers who populate the opera boxes." See Daniil Zhitomirskiy, "Nos - opera D. Shostakovicha" [The Nose—an opera by D. Shostakovich], Proletarskiy muzikant, nos. 7-8 (1929): 33-39. Both articles are superbly translated by Marina Frolova-Walker and Jonathan Walker in Music and Soviet Power, 1917-1932 (Woodbridge, UK: The Boydell Press, 2012), 242-260.

${ }^{11}$ Nikolay Roslavets, “O Psevdo-Proletarskoy Muzike” [On Pseudo-Proletarian Music], Na Putyakh isskusstva (Moscow: Proletkul’t, 1926), 180-192.
} 
compositions. ${ }^{12} \mathrm{He}$ was subsequently forced to resign as the editor of the state publishing house Muzsektor, and fell from grace with the Soviet authorities. He spent the rest of his life in exile in Tashkent, Uzbekistan, writing traditional tonal music, often based on Uzbek folk melodies. ${ }^{13}$ Roslavets was not the only one who experienced brutal consequences in the following two decades, during which experimentation with atonal idioms nearly ceased.

\section{Official Discourse on Atonality in the 1950s}

Although Khrushchev's "Thaw" may have brought a period of relative freedom, musical experimentation still largely developed in the private "underground." ${ }^{14}$ Those young composers who began to experiment with post-tonal musical styles encountered an ever-growing resistance from the musical establishment.

One of the representative articles published during this period in Sovetskaya Muzika was "Paths of Contemporary Innovation” (1958) by Yuri Keldïsh (1907-1995), a respected musicologist, professor at the Leningrad Conservatory (1950-1957), and, at the time, chief editor of Sovetskaya Muzika (19571961). ${ }^{15}$ Keldïsh was responding to an article from Les Lettres françaises, which tried to define "avantgarde" in the arts in 1958 Paris. He claimed that the term "avant-garde" was a code word for new artistic movements that began in France during the 1920s but in recent years had embraced extreme tendencies and completely distanced themselves from tradition. The article then spent a substantial portion on the "formalism" of Schoenberg's twelve-tone system. ${ }^{16}$ Although Keldïsh did not provide any detailed analysis of either Stravinsky's or Schoenberg's music, he was evidently informed about both composers' styles:

Not so long ago, I. Stravinsky's conversion to the "Schoenbergian faith" made a lot of noise. For many years, Stravinsky was considered a staunch opponent of Schoenberg and spoke out condemning his method. As two of the most influential representatives of musical modernism, they competed with each other, challenging each other's claim to being the first. And suddenly Stravinsky began to write in the dodecaphonic style! This seemingly unexpected transformation turned out to be possible, thanks to the aforementioned evolution of the Schoenberg system from expressionism to pure formalism and abstractionism. ${ }^{17}$

Keldïsh's commentary is significant for several reasons. First, he noted Stravinsky's initial resistance to Schoenberg's dodecaphony, of which Keldish surely approved. Then, he underscored that Stravinsky seems to have caught on with the atonal system and "converted" to Schoenberg's so-called atonal "faith." Keldïsh's very comparison of atonality to religion is damning because it signaled the anti-Soviet

\footnotetext{
${ }^{12}$ Ibid., 188.

${ }^{13}$ Nelson, Music for the Revolution, 48-59; and Richard Taruskin, "Restoring Comrade Roslavets," The New York Times, February 20, 2005.

${ }^{14}$ Nancy Condee, "Cultural Codes of the Thaw," in Nikita Khrushchev, ed. William Taubmann, Sergei Khrushchev, and Abbott Gleason (New Haven and London: Yale University Press, 2000), 173-174,

https://doi.org/10.12987/yale/9780300076356.003.0008; and Peter Schmelz, Such Freedom, If Only Musical: Unofficial Soviet Music During the Thaw (New York: Oxford University Press, 2009), https://doi.org/10.1093/acprof:oso/9780195341935.001.0001.

${ }^{15}$ Yuriy Keldïsh, "Puti Sovremennogo Novatorstva” [Paths of Contemporary Innovation], Sovetskaya Muzika, no. 12 (1958): 3-15. Before 1932, Keldïsh was also a member of the Russian Association of Proletarian Musicians that promoted and advocated accessible music for the masses, which included simple music inspired by folk tunes.

${ }^{16}$ Ibid., 8-13.

${ }^{17}$ Ibid., 14. Unless otherwise is noted, all translations from Russian into English are the author's.
} 
character of atonality. As Yuri Kholopov later wrote, "God and Jesus Christ were even bigger enemies to the Soviet regime than Boulez and Webern. And the end of the 1950s was a time period of new persecutions of the church in Soviet Russia."18

Addressing newly composed Soviet musical works, prominent musical figures like Dmitri Kabalevsky (1904-1987), Kirill Molchanov (1922-1982), and Yevgeny Svetlanov (1928-2002) continued to harshly criticize music that they deemed too elitist. The influence of their publications against atonal compositions was considerable, as their stature within the Soviet society was hefty enough to determine the path of one's career. In his article "A Composer is First and Foremost a Citizen," Kabalevsky, a prominent composer who taught at the Moscow Conservatory, took the opportunity to highlight performances of works by Soviet composers (from different republics) at a recent conference of the Composer's Union. ${ }^{19} \mathrm{He}$ especially praised folk aspects of the recently composed symphonic works, which were all written with the purpose of glorifying the Soviet state. ${ }^{20}$ It was not a surprise that Kabalevsky singled out songs entitled "Song about Lenin," "March on, Soldiers!" or "Construction Calls" (a song praising the productivity of hard-working Soviet citizens). The songs were in common time and featured simple, memorable melodies, easy to hum along to. Kabalevsky declared them real contemporary works with national character, as opposed to the definition of "contemporary" as innovative, used, for instance, in early years of the Association of Contemporary Music.

Kabalevsky then focused on two young composers, who-he claimed-needed to change their ways. They were Arvo Pärt (b. 1935) and Edison Denisov (1929-1996). At the time, Denisov in particular was experimenting with serial compositional techniques. The article did not contain any specific analysis; instead, in his discussion, Kabalevsky underscored that Pärt's aesthetic was incomprehensible for the Soviet audience, which was largely reflected in the lack of enthusiastic applause. ${ }^{21}$ During this period, Pärt was a conservatory student and his style was rather adventurous. Although Kabalevsky did not mention the title of Pärt's work that he heard at the performance, it was most likely either Sonatina no. 1 or no. 2, written in 1958-9. ${ }^{22}$ Both works exhibit exciting features that include angular rhythms, sometimes jazzy harmonies, and non-conventional dissonances.

When it came to Denisov's Trio, Kabalevsky wrote:

I was also saddened by E. Denisov's Trio. Surely, the treatment of folksong material, which forms the foundation of this work, could be so much more interesting and fresh. Instead, the composer leaves an impression as if he were looking only for formalist techniques-anything goes, so long as it sounds unusual. But these days you can't surprise anyone with such formal tricks. And should one reduce to this one's entire creativity? ${ }^{23}$

It is unclear which trio Kabalevsky heard, since during this period, Denisov had composed two-a Piano Trio (1954), which he dedicated to Shostakovich, and a Trio for clarinet, bassoon, and violin (1957).

\footnotetext{
${ }^{18}$ Quoted in Aleksandra Drozzina, "Schnittke, Gubaidulina, and Pärt: Religion and Spirituality during the Late Thaw and Early Perestroika," (PhD diss., Louisiana State University, 2020), 1. The original quote is from Yuri Kholopov, "Autsayder Sovetskoy Muziki" [Soviet Music Outsider], Muzïka iz Bïvshego SSSR 1, M. (1994): 122-30, http://www.karamanov.ru/articles/11.html.

${ }^{19}$ Dmitri Kabalevsky, "Kompozitor-prezhde vsego grazhdanin" [A Composer is First and Foremost a Citizen], Sovetskaya Muzïka, no. 2 (1959): 13-20.

${ }^{20}$ Ibid., 13-15.

${ }^{21}$ Kabalevsky did not indicate which composition by Pärt he heard.

${ }^{22}$ Pärt has one other work from this period-Our Garden (1959)—a cantata written for children's choir. However, it was most definitely not what Kabalevsky heard, as Our Garden uses conventionally tonal harmonic style, a 4/4 meter, with a text that describes children's garden, which they had planted themselves.

${ }^{23}$ Kabalevsky, "Kompozitor," 19.
} 
Given that the performance took place in 1959, and it would have been a world premiere, it was probably the latter. Trio for clarinet, bassoon, and violin was composed in an atonal idiom. Further, the work is driven by short motivic ideas rather than a full melody. The musical texture is sparse, reminiscent of Anton Webern's compositions. The trio represents Denisov's deep commitment to atonality and interest in furthering his experiments in this particular style. ${ }^{24}$ Disappointed with both Pärt's and Denisov's works, Kabalevsky ended his review with a scolding statement, in which he disparagingly referred to them as "young composers," who still had to live up to their Soviet identity:

In conclusion, one would like to say that young composers should realize more clearly and more fully the enormous responsibility that lies with them. Of course, everyone can have setbacks - this isn't about one's age [experience] and even talent: there are failures among the talented ones, and a less talented person can at some point rise high and surprise everyone. But the awareness that you are first and foremost a citizen of your society, is the main sentiment that should guide each of us, regardless of age, talent, and degree of creative maturity. ${ }^{25}$ [italics added]

Throughout the 1950s, the seemingly neutral expression "young composers" [molodïye kompozitori] became a derogatory term to address experimental composers, especially those writing atonal music. One composer who was subject to such criticism was Andrei Volkonsky (1933-2008), arguably one of the most important serialists of the Soviet era. ${ }^{26}$ In his article, entitled "Compositions of Young Composers," Kirill Molchanov (1922-1982), a prolific Socialist Realist composer, used the same coded language to smear the reputation of those composers who were not writing in tonal, folk idiom. ${ }^{27}$ Although the article was reviewing two concerts recently given at the Moscow Conservatory, its main aim was to denounce Volkonsky's Cantata Obraz Mira [Image of Peace], which, as Molchanov initially noted, had been widely anticipated at the Moscow Conservatory. Volkonsky was deemed to be one of Conservatory's most talented composition students. The work in question was in four movements, based on the lyrics by the French surrealist poet Paul Éluard (1895-1952). Molchanov noted that Obraz Mira was filled with confusing array of styles from Handel to Prokofiev, and that aside from the beautiful Aria (2nd movement), everything else was cacophonous:

[The first movement] was lifeless and dry. It was devoid of any clear melodic contour. Sharp dissonances pierced the ear, and hysterically repelling sounds from the strings portrayed a painful ecstasy. ${ }^{28}$

Molchanov's rhetoric paralleled other published criticism on atonal music, which included characterization of atonality as "lifeless" [bezzhiznennoy] and "false" [lozhnoy] and defined good compositional style as one based on folk elements. Interestingly, the negative tone of the article was also aimed at the Conservatory pedagogues (among whom was Kabalevsky), who had allegedly failed in guiding Volkonsky.

\footnotetext{
${ }^{24}$ By the 1960s, Denisov became a rather influential composer, who bridged Russian experimental composers with those in the West (Luigi Nono and Pierre Boulez, among other Darmstadt composers). For more on this underground musical development in the Soviet Union, see Schmelz, Such Freedom, 67-130.

${ }^{25}$ Kabalevsky, "Kompozitor," 20.

${ }^{26}$ For an insightful discussion of Volkonsky and his music, see Schmelz, Such Freedom, 67-130.

${ }^{27}$ Kirill Molchanov, “Tvorchestvo molodikh” [Compositions of Young Composers], Sovetskaya Muzïka, no. 7 (1953): 7-10. Molchanov worked in numerous musical genres, especially operas, chamber works, and film music.

${ }^{28}$ Ibid., 8.
} 
In 1954, Yevgeny Svetlanov (1928-2002), an accomplished conductor, composer, and pianist, wrote a review of Volkonsky's Concerto for Orchestra, first performed that summer. ${ }^{29}$ Although Svetlanov initially noted that the work was very much anticipated by students and professors, he was deeply disappointed by it, as, according to him, were the audiences. Svetlanov maintained that the criticism was necessary, since Volkonsky was a rather talented student who was simply on a "false path" [na lozhnom puti]. He proceeded to derogatorily compare the work to music by Western composers (among them Schoenberg and Milhaud), whose works had been banned in the Soviet Union. ${ }^{30}$

The rest of the article focused on the analysis of form and harmony in the Concerto, which echoed some of Molchanov's bombastic language. He spoke of "distorted" sounds and intense dissonance [krayne falshivïye sozvuchiya]. Svetlanov later added that the very title of the work was misleading, since Volkonsky's Concerto did not even feature any call and response (soloist vs. ripieno). He concluded that Volkonsky not only failed to use his full potential as a composer, but he actually misused it. Svetlanov advised Volkonsky to draw on the "realist" tradition, blaming his teacher Yuri Shaporin for misleading his student:

I would like to hope that the young composer, our comrade, in whom we believe and whose failures deeply grieve us all, thinks seriously and realizes the fallacy of his "modernist" diversions. The task of our musical community is to help the growth of this young composer. We must fight for A. Volkonsky — for truth [and] reality of the development of his talent. ${ }^{31}$

In addition to the criticism of prominent composers, pedagogues, and conductors, there seems to have been an unofficial campaign against Volkonsky, as he was also targeted by his peers at the Conservatory. In a publication, commenting on recent concerts at the Moscow Conservatory, its authors-fellow students at the Conservatory-parroted the articles by Molchanov and Svetlanov. ${ }^{32}$ The students praised works dedicated to the Communist Party and, especially, highlighted works that were based on simple, easy to sing melodies, for those works were truly "contemporary"-written recently and in the Soviet spirit. ${ }^{33}$ Then, the focus of the article turned to Volkonsky's Trio, which the reviewers described as lacking melodic beauty. Although the work's intentions were noble (it was dedicated to the October Revolution), its climax was tragic and uninspired. ${ }^{34}$ The authors concluded that Volkonsky had a lot of work to do to better his compositional style. ${ }^{35}$

\section{Kholopov's Rehabilitation of Atonality}

In the 1950s and 1960s, given the official stance on atonality, theoretical writings on the topic were sparse. However, a few notable scholars fought to rekindle its understanding and practice among Soviet

\footnotetext{
${ }^{29}$ Yevgeniy Svetlanov, “Kontsert dlya Orkestra' A. Volkonskogo” [A. Volkonsky’s 'Concerto for Orchestra'], Sovetskaya Muzïka, no. 11 (1954): 27-30.

${ }^{30}$ Ibid., 27.

${ }^{31}$ Ibid., 30.

${ }^{32}$ Inna Barsova, Grigoriy Golovinskiy, and M. Roytershteyn, “Kompozitorskaya molodyozh' Moskovskoy konservatorii," Sovetskaya Muzïka, no. 5 (1952): 26-31. Inna Barsova (b. 1927) became an influential musicologist, with a great number of published articles on a wide range of composers, including the music of Mahler and Scriabin. Interestingly, her stance on atonal music shifted significantly by the 1970s, as she started to publish on the music of non-tonal composers, such as

Hindemith.

33 Ibid., 26.

${ }^{34}$ Ibid., 29-30.

${ }^{35}$ Unfortunately, the article does not go into any more detail about the music itself.
} 
music students. Resisting the official rhetoric surrounding atonality, theorist Yuri Kholopov (1932-2003) strove to analyze atonal music from a purely music-historical perspective rather than political and, in the process, he began to legitimize it. Kholopov approached atonality in a nuanced way-in discussing the significance of non-traditional, not purely tonal compositions, he used history of music theory (both Russian and Western) as his guide. Gradually, Kholopov's publications turned to truly atonal works, which he rebranded as "neotonal." However, the road to neotonality was a lengthy one. As we will see below, Roslavets's music played a major role in Kholopov's project. It could be argued that Kholopov singlehandedly resurrected Roslavets's music from the Soviet oblivion, and, by analyzing it, he rehabilitated it and gave it a new life.

Throughout his Soviet career, Kholopov was careful in his own writings on atonal music. One of the most interesting examples of this is an article that dates to the mid-1960s, ${ }^{36}$ but which was not published until 2008 (which itself speaks volumes about the political restrictions of the 1960s). ${ }^{37}$ In this article, Kholopov encouraged Soviet composers and aspiring musicians to listen to contemporary atonal music. He also provided a listening list, including works like Stravinsky's The Rite of Spring; Bartok's Music for Strings, Percussion, and Celeste; Schoenberg's Survivor from Warsaw; Berg's Lyric Suite; and Webern's Six Pieces for Orchestra.

Further, Kholopov published a great deal on modernist music, most notably on the music of Sergey Prokofiev. ${ }^{38}$ Prokofiev's music was well-known, particularly his works for children (e.g., Peter and the Wolf), the piano (e.g., the "War" sonatas), ballet (e.g., Romeo and Juliet) and opera (e.g., War and Peace), and was more or less sanctioned by the 1960 s. $^{39}$ Thus, Kholopov used it as a starting point to warm the Soviet musical establishment to the concept of extreme chromaticism that he presented simply as an extension of tonal traditions, approaching Prokofiev's non-traditional musical elements very carefully. In addressing Prokofiev's highly chromatic compositional style, Kholopov underscored its historical lineage to the late nineteenth-century chromaticism of Franz Liszt and others. In efforts to re-contextualize triadic posttonality found in much of Prokofiev's oeuvre, Kholopov discussed the new functions of Tonic, Subdominant, and Dominant in contemporary music. He noted:

Contemporary chromatization of diatonicism involves: (1) linear alteration of scale degrees; and (2) contextual chromaticism in parallel-key relationship [odnoimennaya tonal'nost']. This second feature has a built-in enrichment of tonality since it allows for two [raised and lowered] versions of VI, III, and VII chords. Also, this latter feature gives rise to "subtonality" involving two versions of II and IV chords, as well as 7th chords. The most important feature of this new system involves gravitation to the tonic triad. ${ }^{40}$

In the above description, he introduced a novel way of understanding Prokofiev's musical language, not as a whimsical experiment in chromaticism but rather, as a thoughtful and systematic approach to the development of tonal music into the twentieth century. More importantly, Kholopov connected his definition of contemporary chromaticism with the work of the renowned theorist-composer Sergey Taneyev (1856-1915), reminding the reader that "within the same diatonic system, any chord can follow

\footnotetext{
${ }^{36}$ Yuriy Kholopov, “Sovremennaya muzika” [Modern Music], in Idei Khopolova v XXI veke [Kholopov's ideas in the twentyfirst century], ed. T. S. Kyuregyan (Moscow: Muzizdat, 2008), 388-390.

${ }^{37}$ Schmelz, Such Freedom, 26-66.

${ }^{38}$ Yuriy Kholopov, Sovremennïye Cherti Garmonii Prokof'eva [Contemporary Features of Prokofiev's Harmony] (Moscow: Muzika, 1967).

${ }^{39}$ On Prokofiev's tumultuous dealings with the Soviet government, see Morrison, The People's Artist, especially 247-392.

${ }^{40}$ Kholopov, Sovremennïye Chertï, 232-233.
} 
any other chord." ${ }^{41}$ In the section entitled "Atonality," Kholopov tried to discuss the topic by describing atonality as a special type of tonality, whose main difference lies in the absence of a gravitational note or tonic. However, Kholopov underlined that Prokofiev's atonality was distinct from that of Schoenberg and Webern. This latter point was especially important, as Kholopov did not want his readers to conflate Prokofiev's chromatic experiments with those by the composers of the Second Viennese School, who had been severely condemned within the Soviet Union. Kholopov reasserted that for Prokofiev the triad remained the foundational unit of composition. He used "Quarrel" from the Cinderella Suite as an example of Prokofiev's quirky atonality, which is more representative of triadic post-tonality than atonality, with a gravitational center as F. ${ }^{42}$ Kholopov's analytical focus on Prokofiev's music was a wise one, as Prokofiev's compositional aesthetic always adhered to a gravitational point. ${ }^{43}$ Thus, the analyst succeeded in discussing highly chromatic music in two ways: (1) by analyzing music of a Soviet composer, who was not (or, rather, was no longer) controversial in his compositional technique; and (2) by connecting Prokofiev's musical chromaticism to the history of Russian music theory (i.e., Taneyev's theoretical writings). In doing so, Kholopov was able to legitimize Prokofiev's post-tonal innovations as rooted in the history of the development of Russian, and not Western, classic music.

In the 1970s, Kholopov began to gradually combine Western and Russian analytical traditions to discuss contemporary music in general. The article that best expresses Kholopov's eclectic analytical thinking is one on symmetrical modes. ${ }^{44}$ In it, Kholopov compared and contrasted renowned theorist Boleslav Yavorsky's and Olivier Messiaen's modal systems, noting that both developed independently, yet were formed at the same time, with the same goals of equally dividing the octave. ${ }^{45}$ This was a significant connection, as, within the article, Kholopov not only displayed his deep knowledge and understanding of Messiaen's modes, but he also drew parallels between Western and Russian theoretical developments. ${ }^{46}$

Still, it was not until the 1980s that Kholopov (and other Soviet musicologists and theorists) began to publish on atonal music more freely. ${ }^{47}$ However, his terminology still conceptualized atonality as an extension of the tonal traditions, so much so that Kholopov rebranded atonality in Russian music as neotonality [novaya tonal'nost'].$^{48}$ Once again, using the history of music theory as his guide, Kholopov traced neotonality to the writings of Taneyev, who himself was heavily influenced by François-Joseph Fétis's omnitonality (1844). Kholopov concluded that Taneyev discussed the very concept of neotonality

\footnotetext{
${ }^{41}$ Ibid., 218. Sergey Taneyev was an influential composer and theorist, whose textbook on counterpoint-Podvizhnoy kontrapunkt strogogo pis'ma [Invertible counterpoint in the strict style] (Leipzig and Moscow, 1909)—is still highly regarded.

${ }^{42}$ Kholopov, Sovremennïye Chertï, 327-238.

${ }^{43}$ One exception that comes to mind is Prokofiev's Symphony No. 2 (1924), written in Paris. The work is based on twelvetone chords. For an insightful study of this work, see Christopher Segall, "Prokofiev's Symphony No. 2, Yuri Kholopov, and the Theory of Twelve-Tone Chords," Music Theory Online 24, no. 2 (2018), https://doi.org/10.30535/mto.24.2.8.

${ }^{44}$ Yuriy Kholopov, "Simmetrichniye ladï v teoreticheskikh sistemakh Yavorskogo i Messiana" [Symmetrical modes in theoretical systems of Yavorsky and Messiaen], in Muzïka i Sovremennost': Sbornik Statey [Music and Modernity: Collection of Essays] (Moscow: Sovremennïy Kompozitor, 1971), 247-293.

${ }^{45}$ Ibid., 247. For more on Yavorsky's modes, see Roy Guenther, "Varvara Dernova's Garmoniya Skriabina: A Translation and Critical Commentary" (PhD diss., Catholic University of America, 1974); and more recently, Philip A. Ewell, "Rethinking Octatonicism: Views from Stravinsky's Homeland," Music Theory Online 18, no. 4 (2012), https://doi.org/10.30535/mto.18.4.2.

${ }^{46}$ These types of parallels between Western and Russian musical developments are also true for the practice of atonality of the 1960s and 1970s, which thrived in the Soviet Union "underground." See Schmelz, Such Freedom.

${ }^{47}$ During this period, Kholopov's publications included a tome on Webern's music-Anton Vebern: zhizn'i tvorchestvo [Anton Webern: life and work] (Moscow, 1984), which he co-authored with his sister Valentina Kholopova.

${ }^{48}$ Yuriy Kholopov, "Problema novoy tonal'nosti v russkom i sovetskom teoreticheskom muzikoznanii" [The Problem of new tonality in Russian and Soviet theoretical musicology], in Voprosï metodologii Sovetskogo muzïkoznaniya [Questions of Soviet musical methodology], ed. A. I. Kandinskiy (Moscow: Moskovskaya gos. konservatoriya im. P. I. Chaikovskogo, 1981), 100126.
} 
(or lack of tonality) already in the 1880s. Kholopov then identified three important characteristics for neotonality: (1) twelve-toneness is used as the main scale; (2) any chord can follow any other chord; and (3) atonality (absence of tonality) has no ties to tonal tradition. This last characteristic, severing all ties with tonality, was new to Soviet theory. Thus, neotonality became a positive, welcoming, and perhaps politically safer term, replacing the derogatory "atonality" from the earlier years. Further, Kholopov noted that Scriabin's music came closest to atonality, but even then, the harmonies strived to "resolve" to certain other (consonant) harmonies, especially in the Poem of Ecstasy and Prometheus. He concluded with an important remark, acknowledging that one of the significantly progressive theoretical ideas had actually developed during the early Soviet years (1920s) in the works of Nikolai Roslavets-the inventor of his own atonal system of composition. In analyzing Roslavets's music, Kholopov sought to resurrect and relegitimize the music that had been denounced and written out of Soviet history since the 1930s. Thus, by reengaging with Roslavets's atonal music, Kholopov began to establish new Russian classics.

\section{Kholopov's “Neotonality” in Practice}

Example 1 shows Kholopov's analysis of Roslavets's song "Tï ne ushla." Kholopov tried to give validity to Roslavets's music by calling it somewhat "tonal," in which he identified the main group or synthetic chord as a six-note scale that combined $\mathrm{Eb}$ major and $\mathrm{Fb}$ major (indicated on the bottom treble staff as Es dur + Fes dur)..$^{50}$ This claim is ironic since in writings on his own music, Roslavets clearly stated that synthetic chords were meant to replace the tonal system. ${ }^{51}$ Also, throughout the work, there are no tonal centers or traditional key relationships. The work is truly atonal. Because the work lacks tonal centers, it is difficult to hear it within any key (let alone two keys), as suggested by Kholopov. A parallel argument would have been to hear the Petrushka chord as simultaneously in the keys of $\mathrm{C}$ major and $\mathrm{F} \#$ major, since they are part of a larger octatonic collection $\left(\mathrm{OCT}_{0,1}\right)$. Although in the annotated example, Kholopov spelled out all the transpositions of this synthetic chord, he did not comment on the transpositional levels among the chords and their significance. Kholopov's analysis seemed to be cautious. Nonetheless, he took a big step forward in choosing this atonal work built on different transpositions of the same synthetic chord for his analysis.

\footnotetext{
${ }^{49}$ Ibid., 107-108.

${ }^{50}$ Also, the Arabic numbers at the bottom indicate semitonal distances between the contiguous notes, which Kholopov later coins as his hemitonic system.

${ }^{51}$ Of course, it would have been impossible for Kholopov to have known about Roslavets's unpublished lecture on his own music, unless he were a student in Roslavets's class in 1927(!).
} 

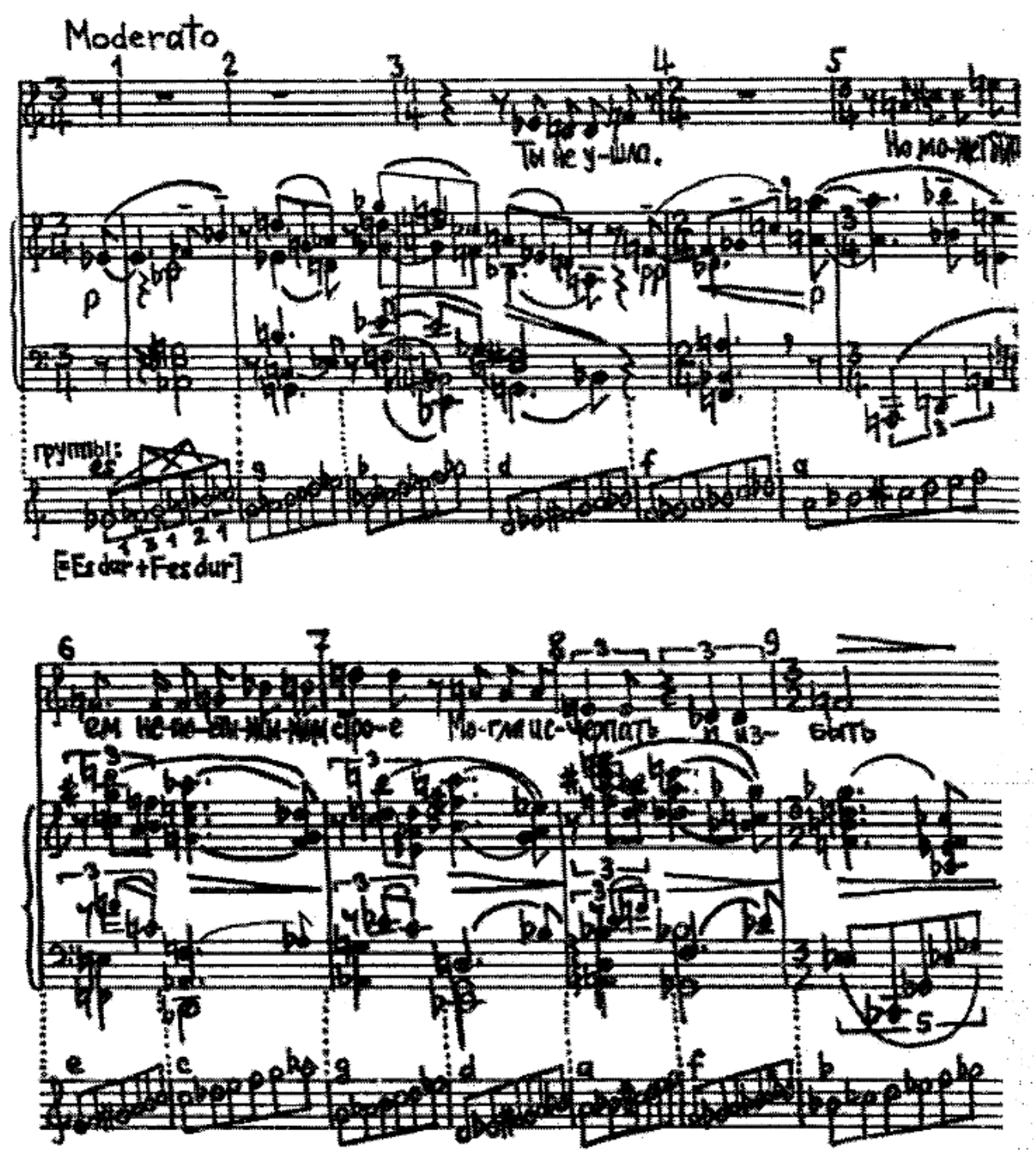

Example 1: Kholopov's analysis of Roslavets's song “Tï ne ushla."

Kholopov took up Roslavets's music again in 2001— ten years after the collapse of the Soviet Unionwhen he attempted to describe a synthetic chord as a set-a collection of notes organized by steps in an ascending order. ${ }^{52}$ Example 2 shows an annotated score of Kholopov's analysis of Roslavets's "Pianissimo" from Three Etudes. Similar to "Tï ne ushla," this work is also based on a single synthetic chord-[A\#, B, C\#, $\mathrm{D}, \mathrm{Eb}, \mathrm{E \#}, \mathrm{F \#}]$ - which is continuously transposed throughout the work. Interestingly, Kholopov calls the set a modal row or a series. ${ }^{53}$ Unfortunately, he did not elaborate on his choice of terminology and, clearly, this kind of terminology-series-is confusing to an Anglophone theorist, who thinks of it as a compositional procedure. (Roslavets was not a serial composer.) Here, Kholopov is attempting to call the main synthetic chord a set (not series) and shows a more sophisticated approach than his previous discussion of "Tï ne ushla."

${ }^{52}$ Yuriy Kholopov, "Emantsipatsiya dissonansa i novaya modal'nost' XX veka" [Emancipation of dissonance and the new modality of twentieth century], in Idei Khopolova v XXI veke [Kholopov's ideas in the twenty-first century], ed. T. S.

Kyuregyan (Moscow: Muzizdat, [2001] 2008), 105-113.

${ }_{53}$ The Arabic numbers above the notes denote the semitones between the contiguous notes. And the rows denote inherent symmetric construction of the set. 


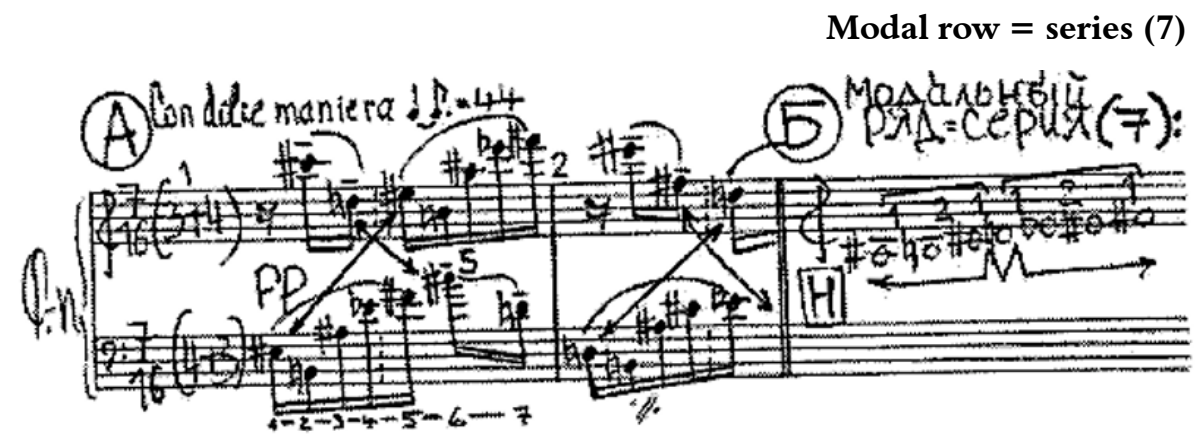

Example 2: Roslavets's "Pianissimo” from Three Etudes (1914); reproduced from Kholopov 2001.

Further, based on Roslavets's compositional output, which Kholopov continued to define as neotonal, for him, twelve-toneness was the main system of contemporary music with sound complexes, such as synthetic chords that could be used both vertically and horizontally (just like Schoenberg's free atonal works). Although Kholopov did not make a big claim about "Pianissimo" as a whole, his annotation of symmetry (within the set) coupled with the semitonal distances already showed a colossal break from the constraints of the Soviet era. ${ }^{54}$

\section{Conclusion}

As we have seen, in the Soviet Union, the history of atonality can be divided into three periods. In its first period, the 1910s-20s, Russian composers and theorists discussed tonality and atonality freely. Nikolai Roslavets's writings on both his own synthetic chords and the music of Schoenberg provided a window to the contemporary musical world beyond Soviet borders. In its second period, the 1930s-1960s, atonality was used as a weapon to censor and condemn composers, both domestic and foreign. In addition, severely negative reviews by Kabalevsky, Molchanov, and Svetlanov, among others, used atonality to smear the reputation of aspiring Russian composers, such as Volkonsky, who looked toward atonal compositional techniques. However, by the 1960s, Yuri Kholopov spearheaded a renaissance of atonal music study and reevaluated its significance in the development of Soviet music. Even though it was hard to perform atonal music without incurring scathing criticism, Kholopov found a way to discuss it by connecting it to past tonal traditions. Finally, in its third and last period (from the 1970s on), the coinage of neotonality allowed Kholopov to discuss music that did not in fact have any connections with tonal traditions. His detailed analyses of atonal music rekindled a dialogue with early Soviet (positive) publications on the topic, as well as atonal works written during that period, especially those by Nikolai Roslavets. It is in this third period that the study of atonality began to truly flourish in Russia.

\footnotetext{
${ }^{54}$ For more on Roslavets's symmetric chord-paths, especially in "Pianissimo," see Bazayev, “Triple Sharps,” 111-31. Also, more recent Russian scholarship on atonality is heavily influenced by Western theoretical concepts. These include a monograph on serial music by Kholopov's protégé Svetlana Kurbatskaya, entitled Serial Music: Questions of History, Theory, Aesthetics, which described various terms pertaining to serialism that are synonymous with Western concepts. See Svetlana Kurbatskaya, Seriynaya muzïka: voprosï istorii, teorii, estetiki [Serial music: questions of history, theory, and aesthetics] (Moscow: Sfera, 1996). For a brief commentary on this book, see Zachary Cairns, "Svetlana Kurbatskaya on Serial Music: Twelve Categories of 'Twelve-Toneness'," Gamut 5, no. 1 (2012): 109-131.
} 


\section{Selected Bibliography}

Barsova, Inna, Grigoriy Golovinskiy, and M. Roytershteyn. “Kompozitorskaya molodyozh’ Moskovskoy konservatorii” [Young composers of the Moscow Conservatory]. Sovetskaya muzika, no. 5 (1952): $26-31$.

Bazayev, Inessa. "Scriabin's Atonal Problem.” Music Theory Online 24, no. 1 (2018). https://doi.org/10.30535/mto.24.1.1.

. "Triple Sharps, $Q_{\text {nt }}$ Relations, and Symmetries: Orthography in the Music of Nicolai Roslavets." Music Theory Spectrum 35, no. 1 (Spring 2013): 111-31. https://doi.org/10.1525/mts.2013.35.1.111.

Cairns, Zachary. "A Glimpse at Iurĭ Kholopov's Garmonicheskĭ analiz.” Music Theory Online 20, no. 3 (2014). https://doi.org/10.30535/mto.20.3.7.

_. "Svetlana Kurbatskaya on Serial Music: Twelve Categories of 'Twelve-Toneness'." Gamut 5, no. 1 (2012): 109-131.

Condee, Nancy. "Cultural Codes of the Thaw." In Nikita Khrushchev, edited by William Taubmann, Sergei Khrushchev, and Abbott Gleason, 160-176. New Haven and London: Yale University Press, 2000. https://doi.org/10.12987/yale/9780300076356.003.0008.

Drozzina, Aleksandra. "Schnittke, Gubaidulina, and Pärt: Religion and Spirituality during the Late Thaw and Early Perestroika." PhD diss., Louisiana State University, 2020.

Ewell, Philip A. "Rethinking Octatonicism: Views from Stravinsky's Homeland." Music Theory Online 18, no. 4 (2012). https://doi.org/10.30535/mto.18.4.2.

Fairclough, Pauline. Classics for the Masses. New Haven and London: Yale University Press, 2016. https://doi.org/10.12987/yale/9780300217193.001.0001.

Fay, Laurel E. Shostakovich: A Life. New York: Oxford University Press, 2000.

Frolova-Walker, Marina, and Jonathan Walker. Music and Soviet Power, 1917-1932. Woodbridge, UK: The Boydell Press, 2012.

Guenther, Roy J. "Varvara Dernova's Garmoniya Skriabina: A Translation and Critical Commentary." $\mathrm{PhD}$ diss., Catholic University of America, 1979.

Guldberg, Jørn. "Socialist Realism as Institutional Practice: Observations on the Interpretation of the Works of Art from the Stalin Period." In The Culture of the Stalin Period, edited by Hans Günther, 149-177. New York: Palgrave Macmillan, 1990. https://doi.org/10.1007/978-1-349-20651-3_8.

Kabalevskiy, Dmitriy. "Kompozitor-prezhde vsego grazhdanin" [A Composer is First and Foremost a Citizen], Sovetskaya Muzika, no. 2 (1959): 13-20.

Keldïsh, Yuriy. "Proletariat Musicians." In Sovetskaya Entsiklopediya [Soviet Encyclopedia], vol. 6. Moscow: Sovetskiy Kompozitor, 1978.

. "Puti Sovremennogo Novatorstva" [Paths of Contemporary Innovation]. Sovetskaya Muzika, no. 12 (1958): 3-15.

. "Ballet Stal'noi Skok' i ego avtor-Prokofiev" [Ballet Le Pas d'Acier and its composerProkofiev]. Proletarskiy Muzikant, no. 6 (1929): 12-19. Reprinted in Yuriy Vsevolodovich Keldish. Vospominaniya, issledovaniya, materiali, dokumenti [Yuriy Vsevolodovich Keldish: Memoirs, research, materials, documents], edited by N. I. Teterina, 348-255. Moscow: Gosudarstvennïy Institut Iskusstvoznaniya, 2015. 
Kholopov, Yuriy. "Emantsipatsiya dissonansa i novaya modal'nost' XX veka” [Emancipation of dissonance and the new modality of the twentieth century]. In Idei Khopolova $v$ XXI veke [Kholopov's ideas in the twenty-first century], edited by T. S. Kyuregyan, 105-113. Moscow: Muzizdat, 2008 [2001].

. "Sovremennaya muzika" [Contemporary Music], originally unpublished article. In Idei Khopolova $v$ XXI veke [Kholopov's ideas in the twenty-first century], edited by T. S. Kyuregyan, 388-390. Moscow: Muzizdat, 2008.

. "Problema novoy tonal'nosti v russkom i sovetskom teoreticheskom muzïkoznaniı̈" [The Problem of new tonality in Russian and Soviet music theory]. In Idei Khopolova $v$ XXI veke [Kholopov's ideas in the twenty-first century], edited by T. S. Kyuregyan, 199-219. Moscow: Muzizdat, 2008 [1981].

_- "Autsayder Sovetskoy Muziki" [Outsider of Soviet Music]. Muzika iz B̈̈vshego SSSR 1. Vipusk 1, 122-30. Moscow: 1994. http://www.karamanov.ru/articles/11.html.

—. "Simmetrichnïye ladï v teoreticheskikh sistemakh Yavorskogo i Messiana" [Symmetrical modes in theoretical systems of Yavorsky and Messiaen]. In Muzika i Sovremennost': Sbornik Statei [Music and Modernity: Collection of Essays], 247-293. Moscow: Sovremennïy Kompozitor, 1971.

- Sovremennïye Cherti Garmonii Prokof eva [Contemporary Features of Prokofiev's Harmony]. Moscow: Izdatsel'stvo Muzika, 1967.

Kholopov, Yuri, and Valentina Kholopova. Anton Vebern: zhizn' i tvorchestvo [Anton Webern: life and works]. Moscow, 1984.

Kurbatskaya, Svetlana. Seriynaya muzika: voprosï istorii, teorii, estetiki [Serial music: question of history, theory, and aesthetics]. Moscow: Sfera, 1996.

Maes, Francis. A History of Russian Music: From Kamarinskaya to Babi Yar. Translated by Arnold J. Pomerans and Erica Pomerans. Berkeley and Los Angeles: University of California Press, 2002.

Molchanov, Kirill. "Tvorchestvo molodïkh" [Compositional oeuvre of young composers]. Sovetskaya muzika, no. 7 (1953): 7-10.

Morrison, Simon. The People's Artist: Prokofiev's Soviet Years. New York: Oxford University Press, 2009.

—. "Romeo and Juliet's Happy Ending." Three Oranges, no. 17 (2009).

Nelson, Amy. Music for the Revolution: Musicians and Power in Early Soviet Russia. University Park, Pennsylvania: The Pennsylvania University Press, 2004.

Roslavets, Nikolay. "Novaya sistema organizatsii zvuka i novïye metodï prepodavaniya teorii kompozitsii: Tezisy doklada" [The New System of Tone Organization and New Methods of Teaching the Theory of Composition: Lecture Theses]. An unpublished lecture given at the Stravinsky MusicVocal courses in Moscow, RGALI, file 2569, 1927.

- "O Psevdo-Proletarskoy Muzïke" [On Pseudo-Proletarian Music]. In Na Putyakh isskusstva, 180-192. Moscow: Proletkul't, 1926.

—. "Nik. A. Roslavets o sebe i svoyom tvorchestve" [Nik. A. Roslavets on Himself and His Works]. Sovremennaya Muzika, no. 5 (1924): 132-138.

—. "Lunnïy P'ero Arnol'da Shenberga" [Pierrot Lunaire by Arnold Schoenberg]. K novïm beregam, no. 3 (1923): 28-33.

Schmelz, Peter. Such Freedom, If Only Musical: Unofficial Soviet Music During the Thaw. New York: Oxford University Press, 2009. https://doi.org/10.1093/acprof:oso/9780195341935.001.0001. 
Schwarz, Boris. "Opera, Ballet, and Orchestral Music, 1920's." In Music and Musical Life in Soviet Russia, 1917-1981. Bloomington: Indiana University Press, 1983.

"Arnold Schoenberg in Soviet Russia." Perspectives of New Music 4, no. 1 (Autumn-Winter, 1965): 86-94. https://doi.org/10.2307/832529.

Segall, Christopher. "Prokofiev's Symphony no. 2, Yuri Kholopov, and the Theory of Twelve-Tone Chords." Music Theory Online 24, no. 2 (2018). https://doi.org/10.30535/mto.24.2.8.

Seinen, Nathan. "Kutuzov's Victory, Prokofiev's Defeat: The Revisions of 'War and Peace'." Music and Letters 90, no. 3 (August 2009): 399-431. https://doi.org/10.1093/ml/gcp019.

Skorik, M. "Prokof'ev i Schenberg" [Prokofiev and Schoenberg]. Sovetskaya Muzika, no. 1 (1962): 34-38.

Sollertinskiy, Ivan. Arnold Shenberg [Arnold Schoenberg]. Leningrad: Leningrad Philharmonia.

Reprinted in Pamyati I. I. Sollertinskogo: Vospomenaniya, Materiali, Issledovaniya [In Memory of I. I. Sollertinskiy: Memoirs, Materials, Research], edited by L. Mikheyeva. Leningrad and Moskva: Sovetskiy Kompozitor, [1934] 1974.

Svetlanov, Yevgeniy. “'Kontsert dlya orkestra A. Volkonskogo” [A. Volkonsky's Concerto for Orchestra]. Sovetskaya Muzika, no. 11 (1954): 27-30.

Taneyev, Sergey. Podvizhnoy kontrapunkt strogogo pis'ma [Invertible counterpoint in the strict style]. Leipzig and Moscow, 1909.

Taruskin, Richard. "Restoring Comrade Roslavets." The New York Times, February 20, 2005.

Vayl', Pyotr, and Aleksandr Genis, 60-ï: mir sovetskogo cheloveka [The '60s: The World of a Soviet Person], Second Corrected Edition. Moscow: Novoye literanurnoye obozreniye, 1998.

Walsh, Stephen. Stravinsky: A Creative Spring: Russia and France, 1882-1934. Los Angeles: University of California Press, 2002.

Zhitomirskiy, Daniil. "Nos - opera D. Shostakovicha” [The Nose-an opera by D. Shostakovich]. Proletarskiy muzikant, nos. 7-8 (1929): 33-39. 